
DOI: http://dx.doi.org/10.4314/njbas.v21i2.8

\title{
Influence of Compression Stresses on Timber Potentials of Plantation Grown Eucalyptus camaldulensis Denhn in North-Western Nigeria
}

\author{
${ }^{* 1}$ A.A. Malami and ${ }^{2}$ B. Olufemi \\ 1Department of Forestry and Fisheries, Faculty of Agriculture, Usmanu Danfodiyo University Sokoto. \\ 2Department of Forestry and Wood Technology, Federal University of Technology, Akure \\ [Corresponding Author, E-mail: aamalami@yahoo.com; 瀂: +23465672287]
}

\begin{abstract}
A study was conducted on the influence of compression stresses on timber potentials of plantation grown $E$. camaldulensis (Denhn) in North-western Nigeria, with a view to finding an alternative to the over exploited rainforest species. Five 20 year old trees each from Sokoto, Kebbi and Zamfara states were selected and felled for the study. These were cut into top, middle and bottom regions. A total of 225 samples were cut for laboratory analysis according to BS881:74 standard procedures. Laboratory analysis was carried out at Forestry Research Institute of Nigeria (FRIN), Ibadan, using Universal Testing Machine (UTM). ANOVA was used to analyze the data and mean separation was done using Duncan's New Multiple Range Test. Results of the study revealed overall mean compression stress values of $51.85 \mathrm{~N} / \mathrm{mm}^{2}$ and $5.00 \mathrm{~N} / \mathrm{mm}^{2}$ parallel $(/ / \mathrm{g})$ and perpendicular (\lrcorner $\left.\mathrm{g}\right)$ to grain respectively. ANOVA showed that differences between means in compression stress perpendicular to grain were highly significant while region/location interaction also revealed significant differences. Similarly, location/region and tree/region interactions were highly significant. It is recommended that $E$. camaldulensis be added in to the list of exploitable species in North-western Nigeria as it provides suitable alternative to species hitherto exploited and that further research should be carried out on wood in service to study the peculiarities of timber behaviour under actual service conditions.
\end{abstract}

Keywords: Compression, stress, timber, parallel, perpendicular, grain and plantation

\section{INRODUCTION}

Compression stress is the ability of a wood member to resist the impact of forces or loads acting along the same axis and trying to shorten a dimension or reduce the volume of the wood. Wood in service is constantly interacting with so many forces, of which compressive forces are the most prominent. According to Akpan (2006), high strength in longitudinal compression is required of timber used as columns, props and chair legs. In evaluating this property therefore, it is necessary to ensure that the specimen does not buckle during loading thereby subjecting it to bending rather than a compressive stress (Desch, 1992). This is because, unlike other materials, timber is significantly weaker in longitudinal compression than in longitudinal tension with value as low as one quarter (Curtu et al., 1981; Porter 2001). For some selected end uses such as railway sleepers, rollers, wedges, bearing blocks and bolted timbers, resistance to crushing is an important property. Timbers which are high in density have high compression strength across the grain (Akpan, 2006). Studies have revealed that wood is weaker in compression perpendicular to the grain than it is in compression parallel to the grain (Curtu et al., 1981; Stalnaker and Harris, 1989). The aim of this research is to study the compression stresses of $E$. camaldulensis in relation to timber fabrication with a view to finding an alternative to the dwindling timber species hitherto exploited in the study area.

\section{MATERIALS AND METHODS}

\section{The study area}

The study was conducted at the permanent site, Usmanu Danfodiyo University, Sokoto. Sokoto State is located in the Sudan savanna zone in the extreme North-Western part of Nigeria between latitudes $12^{\circ} 0^{\prime}$ and $13^{\circ} 58^{\prime} \mathrm{N}$ and longitudes $4^{\circ} 8^{\prime}$ and $6^{\circ} 54^{\prime} \mathrm{E}$ (Mamman et al., 2000). It shares common border with Niger Republic in the north, Kebbi State to the south west and Zamfara State to the east. The inhabitants are predominantly Hausa and Fulani. Their economic activities include farming, rearing of domestic animals (goats, sheep and cattle) and trading.

Climate is characterized by long dry season from October/November - April/May and a short rainy season from April - September/October but may vary. The dry season consists of a cold dry spell (harmattan) roughly from November to January, followed by a hot dry spell from February to April. Annual rainfall is about $760 \mathrm{~mm}$ per annum and is unevenly distributed (Ojanuga, 2004). The rainfall starts in late May and ends 
September/October. The temperature ranges from $20^{\circ} \mathrm{C}-39^{\circ} \mathrm{C}$ but is most severe in March and April. In February, the mean maximum and minimum temperatures are $19^{\circ} \mathrm{C}$ and $38^{\circ} \mathrm{C}$ respectively with the relative humidity of about $52 \%$ to $56 \%$ (Senchi, 2005). The vegetation is characterized by grasses and scattered trees which include tree species such as Acacia nilotica, B. aegyptiaca and Azadirachta indica etc (Fatubarin, 2004). Soil is predominantly sandy to sandy-loam with low level of fertility. It is particularly poor in primary nutrients - nitrogen, phosphorus and potassium (Fatubarin, 2004).

\section{Determination of compression stress parallel to the grain}

The test specimens (225 in number) were cut to standard sizes of $60.00 \mathrm{~mm} \times 20.00 \mathrm{~mm} \times 20.00 \mathrm{~mm}$ each in line with BS 881:74. Each of the specimens was loaded in to the machine with the direction of the wood grains parallel to the axis of the piston of the machine (powered by an electric motor) at a rate of $0.01 \mathrm{~mm} / \mathrm{s}$ until failure occurred. A special cage is used to ensure that the material does not buckle during loading. The failure load was then recorded and used for calculating the strength value by the following formula (Desch, 1992):

$$
\text { Strength value }=\frac{\text { Load to failure }}{\text { Cross sectional area }}\left(\mathrm{N} / \mathrm{mm}^{2}\right)
$$

With the above relationship, the compression strength parallel to the grain of the wood was computed for each of the 225 wood specimens.

\section{Determination of compression stress perpendicular to grain}

The 225 test specimens were cut to standard sizes of $60.00 \mathrm{~mm} \times 20.00 \mathrm{~mm} \times 20.00 \mathrm{~mm}$ in line with BS $881: 74$. These were loaded into the machine at a rate of $0.01 \mathrm{~mm} / \mathrm{s}$ until failure occurred. The loading of the test specimen was done in such a way that the direction of the wood grain was perpendicular to the axis of the wood grain. The compression stress perpendicular to the grain (radial) for each of the test specimens was computed in line with the equation described above.

\section{Data Analysis}

The data collected were subjected to Analysis of variance (ANOVA) to compare the differences in the three locations. Also regression analysis was carried out in order to establish relationship between compression stress and load for the three locations.

\section{RESULTS AND DISCUSSIONS \\ Compression stress parallel to grain}

From the results it is indicated that in Sokoto, the compression stress parallel to the grain varied from $47.24 \mathrm{~N} \mathrm{~mm}^{-2}$ to $69.87 \mathrm{~N} \mathrm{~mm}^{-2}$ with a mean of $62.57 \mathrm{~N}$ $\mathrm{mm}^{-2}$. In Kebbi and Zamfara states, it varied from $50.81 \mathrm{~N} \mathrm{~mm}^{-2}$ to $71.98 \mathrm{~N} \mathrm{~mm}^{-2}$ and $37.44 \mathrm{~N} \mathrm{~mm}^{-2}$ to $78.55 \mathrm{~N} \mathrm{~mm}^{-2}$, with the mean of $64.37 \mathrm{~N} \mathrm{~mm}^{-2}$ and $58.61 \mathrm{~N} \mathrm{~mm}^{-2}$ respectively. The overall mean value of the compression stress across the north-western zone was $61.85 \mathrm{~N} \mathrm{~mm}^{-2}$. Table 1 presents the values of the compression stress parallel to the grain and the ANOVA for same is presented in Table 2. The relationship of compression stress parallel to the grain and failure loads in the ecological area is presented in Figure 1. From the figure, it is apparent that there was perfect positive relationship in all the three locations which is indicative of the linearity of the compression stress effect on load but the intercept differs.

Table 1: Compression Stress of Tree Samples Parallel to Grain for the Three Locations ( $\mathrm{N} \mathrm{mm}^{-2}$ )

\begin{tabular}{llll}
\hline Portion & Sokoto & Kebbi & Zamfara \\
\hline Bottom & $63.23 \pm 7.04$ & $61.13 \pm 5.82$ & $53.81 \pm 1.84$ \\
Middle & $62.62 \pm 4.37$ & $63.47 \pm 4.29$ & $67.87 \pm 2.24$ \\
Top & $61.87 \pm 7.65$ & $68.52 \pm 2.69$ & $54.14 \pm 2.64$ \\
Means & $62.57 \pm 5.62$ & $64.37 \pm 3.31$ & $61.85 \pm 1.00$ \\
\hline
\end{tabular}

Table 2: ANOVA of Compression Stress Parallel to Grain

\begin{tabular}{|c|c|c|c|c|c|}
\hline Source of variation & SS & $\mathrm{DF}$ & M S & $\mathrm{F}$ & P Value \\
\hline Tree & 2356.35 & 4 & 589.086 & $11.813^{\star \star}$ & 0.00 \\
\hline Location & 1305.24 & 2 & 652.651 & $13.087^{\star \star}$ & 0.00 \\
\hline Region & 220.317 & 2 & 110.159 & $2.209^{n s}$ & 113 \\
\hline Location- Tree & 5024.06 & 8 & 628.008 & $12.593^{\star *}$ & 0.00 \\
\hline Location- Region & 1254.817 & 4 & 313.704 & $6.29^{\star \star}$ & 0.00 \\
\hline Tree-Region & 727.811 & 8 & 90.976 & $1.824^{\mathrm{ns}}$ & 0.075 \\
\hline Error & 8976.427 & 180 & 49.869 & & \\
\hline Total & 26730.199 & 224 & & & \\
\hline
\end{tabular}




\section{Comp. Stress//g. Sokoto}

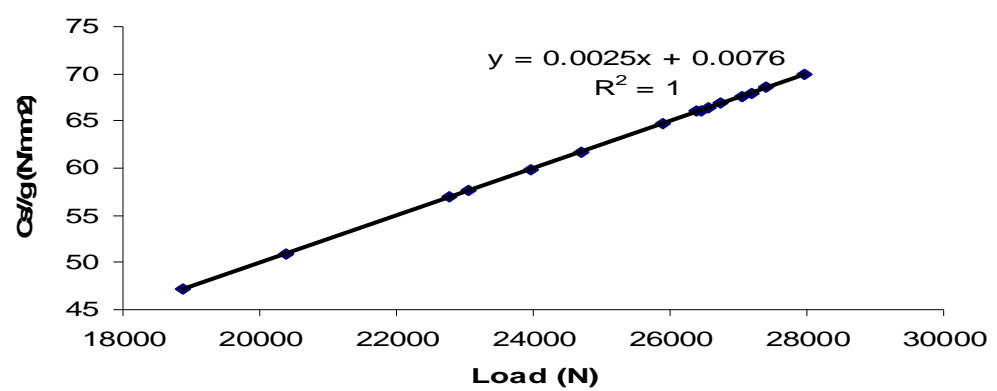

(a)

Comp.Stress//g. Kebbi

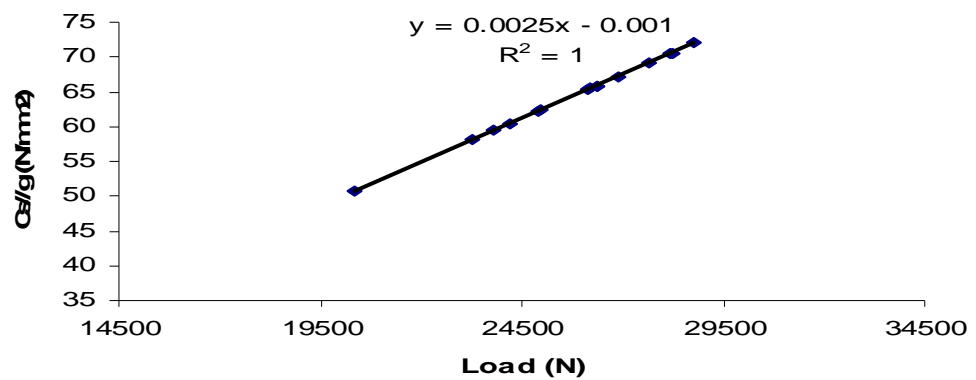

(b)

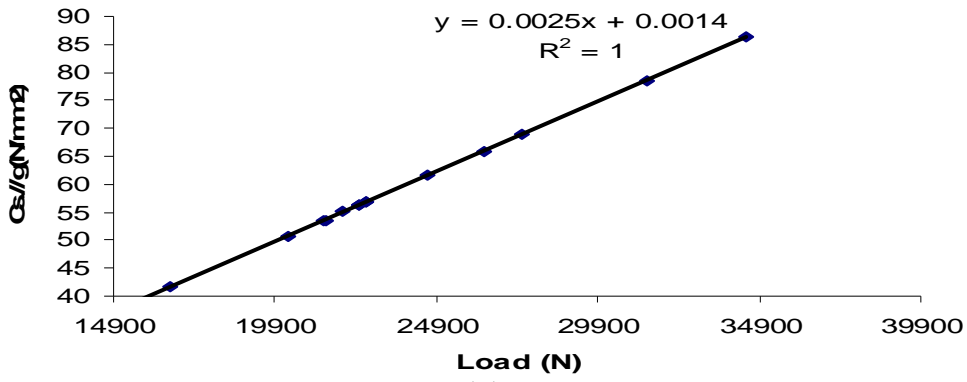

(c)

Figure 1a,b,c: Relationship between compression stress parallel to grain and load to failure

From the results the overall mean compression stress parallel to grain of $E$. camaldulensis at $61.85 \mathrm{~N} \mathrm{~mm}^{-2}$ (Table 1) falls under the moderate category, based on the grouping by Ghelmeziu (1981). In comparison with other eucalyptus species it can be said that $E$. camaldulensis is higher than its counterparts like $E$. saligna $\left(39.43 \mathrm{~N} \mathrm{~mm}^{-2}\right)$, E. robusta $\left(28.57 \mathrm{~N} \mathrm{~mm}^{-2}\right), E$. grandis $\left(45.79 \mathrm{~N} \mathrm{~mm}^{-2}\right)$ and $E$. butryoides $\left(55.29 \mathrm{~N} \mathrm{~mm}^{-}\right.$ $\left.{ }^{2}\right)$. It is however lower in this respect than $E$. cloeziana $\left(75 \mathrm{~N} \mathrm{~mm}^{-2}\right)$ (FPR, 1969). This places it at very good advantage.

Similarly, the wood species is higher in resistance in comparison with other wood species that are used for timber in Nigeria. Some of these wood species with inferior compression stresses parallel to grain include Triplochiton scleroxylon $\left(28.2 \mathrm{~N} / \mathrm{mm}^{2}\right)$, Pycanthus angolensis $\left(39 \mathrm{~N} \mathrm{~mm}^{-2}\right)$, Terminalia superba $\left(46 \mathrm{~N} \mathrm{~mm}^{-}\right.$ $\left.{ }^{2}\right)$, Khaya ivorensis $\left(46 \mathrm{~N} \mathrm{~mm}^{-2}\right)$, Guarea thompsonii $\left(59 \mathrm{~N} \mathrm{~mm}^{-2}\right)$ and Entandrophragma candollei $\left(59 \mathrm{~N} \mathrm{~mm}^{-}\right.$ 2). It is however lower than Chlorophora exelsa (62N $\mathrm{mm}^{-2}$ ) (Ghelmeziu, 1981); Kwame 2001); Hall 1998); USFPL 2001); Tarziu 1983); Ademiluyi 1984); and Akpan, 2006). In the same respect, $E$. camaldulensis is also at an advantage with with these recorded values over other frequently used Nigerian timber for structural purposes. Some of these include Danielia kleinei (41.39 $\left.\mathrm{N} / \mathrm{mm}^{2}\right)$, Uapaca guinensis (59.4N $\left.\mathrm{mm}^{-2}\right)$, Combretodendron macrocarpum (60N mm-2), Canarium schwenfurthei (36N mm-2), Berlinia confuse (53N mm-2), 
Gossweilodendron balsamiferum (43.2N mm-2), Tectona grandis $\left(53 \mathrm{~N} \mathrm{~mm}^{-2}\right)$, Mitragyna ciliata (44N $\mathrm{mm}^{-2}$ ) and Terminalia ivorensis $\left(45 \mathrm{~N} \mathrm{~mm}^{-2}\right)$ (USFPL, 2001; Hall, 1998; Curtu and Ghelmeziu, 1984 and Boiangu et. al,. 1982). In a recent study in North eastern Nigeria, Neem (Azadirachta indica) was found to have a compression stress parallel to grain of $65.19 \mathrm{~N}$ $\mathrm{mm}^{-2}$ (Akpan, 2006). It is concluded that it would be suitable for use as structural timber. With the values of Eucalyptus and Neem falling within the same moderate class of compression parallel to grain, it can also be concluded that it will be suitable for use as structural timber. In line with NCP 2(1973), the value of compression stress parallel to grain of $\mathrm{E}$. camaldulensis is higher compared to majority of recommended structural timber. Other species, in this respect are Turreanthus africana $\left(49 \mathrm{~N} \mathrm{~mm}^{-2}\right)$, Holoptelia grandis $\left(59 \mathrm{~N} \mathrm{~mm} \mathrm{~m}^{-2}\right)$, Tieghemella heckeli $\left(60 \mathrm{~N} \mathrm{~mm}^{-2}\right)$, Oxystigma oxyphyllum $\left(57 \mathrm{~N} \mathrm{~mm}^{-2}\right)$, Guarea cedrata $\left(57 \mathrm{~N} \mathrm{~mm}^{-2}\right)$, Guarea thompsoni $\left(59 \mathrm{~N} \mathrm{~mm}^{-2}\right)$, Daniellia Ogea (41 $\left.\mathrm{N} \mathrm{mm}^{-2}\right)$, Lovoa trichiloides $\left(52 \mathrm{~N} \mathrm{~mm}^{-2}\right)$, Antiaris africana $\left(42 \mathrm{~N} \mathrm{~mm}^{-2}\right)$, Sterculia oblonga ( $57 \mathrm{~N}$ $\mathrm{mm}^{-2}$ ) and Alstonia boonei $\left(27 \mathrm{~N} \mathrm{~mm}^{-2}\right)$. This higher value puts it at an advantage over many of the commonly used species especially where there is need to support load in compression parallel to grain eg chair and table supports (legs). The analysis of variance of the compression stress parallel to grain is highly significant between the trees and locations as well as between location/tree and tree/region interactions at $1 \%$ level of probability. Differences between regions as well as between tree/region interactions were not significant (Table 2).

\section{Compression stress perpendicular to grain}

The findings show that compression stress perpendicular to the grain varied from $4.00 \mathrm{~N} \mathrm{~mm}^{-2}$ to $6.48 \mathrm{~N} \mathrm{~mm}^{-2}$ in Sokoto state with a mean value of $5.10 \mathrm{~N}$ $\mathrm{mm}^{-2}$. Similarly, values ranged from $4.18 \mathrm{~N} \mathrm{~mm}^{-2}$ to $5.90 \mathrm{~N} \mathrm{~mm}^{-2}$, with a mean value of $4.99 \mathrm{~N} \mathrm{~mm}^{-2}$ in Kebbi state. In Zamfara state, the values are within the range of $3.83 \mathrm{~N} \mathrm{~mm}^{-2}$ and $5.72 \mathrm{~N} \mathrm{~mm}^{-2}$ with a mean value of $4.89 \mathrm{~N} \mathrm{~mm}^{-2}$. The overall mean of the compression stress perpendicular to the grain across the north-west ecological zone was $4.89 \mathrm{~N} \mathrm{~mm}^{-2}$. Table 3 shows the compression stress perpendicular to the grain of the tree species under study. ANOVA is presented in Table 4 , while Figure 2 shows the relationship between compression stress perpendicular to the grain and the failure loads in the three study sites.

Table 3: Compression Stress of Tree Samples Perpendicular to Grain for the Three Locations $\left(\mathrm{N} \mathrm{mm}^{-2}\right)$

\begin{tabular}{lcll}
\hline Portion & Sokoto & Kebbi & Zamfara \\
\hline Bottom & $4.86 \pm 0.88$ & $5.12 \pm 0.61$ & $5.12 \pm 0.38$ \\
Middle & $5.36 \pm 0.44$ & $4.97 \pm 0.63$ & $4.60 \pm 0.47$ \\
Top & $5.09 \pm 0.55$ & $4.89 \pm 0.47$ & $4.96 \pm 0.67$ \\
Means & $5.10 \pm 0.24$ & $4.99 \pm 0.41$ & $4.89 \pm 0.29$ \\
\hline
\end{tabular}

Table 4: ANOVA of Compression Stress Perpendicular to Grain

\begin{tabular}{lccccc}
\hline Source of variation & S.S & D.F & M.S & $F$ & P. Value \\
\hline Tree & 3.073 & 4 & 0.768 & $3.233^{\star *}$ & 0.014 \\
Location & 1.672 & 2 & 0.836 & $3.519^{\star}$ & 0.032 \\
Region & 4.768 & 2 & 2.384 & $10.033^{\star *}$ & 0.00 \\
Location- Tree & 13.093 & 8 & 1.637 & $6.888^{\star *}$ & 0.00 \\
Location- Region & 7.946 & 4 & 1.986 & $8.360^{* \star}$ & 0.00 \\
Tree-Region & 10.447 & 8 & 1.306 & $5.496^{\star *}$ & 0.00 \\
Error & 42.769 & 180 & 0.236 & & \\
Total & 128.330 & 224 & & & \\
\hline & *The mean difference is significant at 5\% level $(\mathrm{P}<0.05)$ & ${ }^{* *}$ The mean difference is highly significant $(P<0.01)$ &
\end{tabular}

The value of compression stress perpendicular to grain of $5.00 \mathrm{~N} \mathrm{~mm}^{-2}$ for $E$. camaldulensis is lower than the value obtained for $E$. grandis and E. terreticornis hybrid with $12.07 \mathrm{~N} \mathrm{~mm}^{-2}$ (Martin et. al., 2007). However, in comparison to species commonly used for structural timber in Nigeria, the species averagely fits well in to the class. According to Ghelmeziu (1981); Ademiluyi (1984); Desch (1992); ALS (2000); USFPL (2001), some of the known timber species used in Nigeria and their compression stress perpendicular to grain are Triplochiton scleroxylon (3.9N mm-2), Terminalia superba $(9 \mathrm{~N} \mathrm{~mm}-2)$, Khaya ivorensis $\left(7 \mathrm{~N} \mathrm{~mm}^{-2}\right)$, Entandrophragma cylindricum (8.5N $\left.\mathrm{mm}^{-2}\right)$,

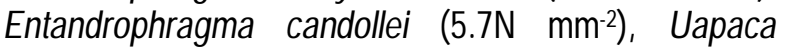
guineensis $\left(11 \mathrm{~N} \mathrm{~mm}^{-2}\right), \quad$ Gossweilerodendron balsamiferum $\left(5.9 \mathrm{~N} / \mathrm{mm}^{2}\right)$, Mitragyna ciliata $\left(6 \mathrm{~N} \mathrm{~mm}^{-2}\right)$, 
Terminalia ivorensis $\left(7 \mathrm{~N} \mathrm{~mm}^{-2}\right)$ and Ceiba pentandra $\left(2 \mathrm{~N} \mathrm{~mm}^{-2}\right)$. With this value, E. camaldulensis compares well with those timber species recommended for structural use by NCP 2 (1973). The timber species afore mentioned are all included in the species recommendation list for engineering purposes in Nigeria. Since species with lower compression stress perpendicular to grain value as low as $2 \mathrm{~N} \mathrm{~mm}^{-2}$ qualifies for utilization, E. camaldulensis, with $5.00 \mathrm{~N}$ $\mathrm{mm}^{-2}$ is at an advantage for same, and hence found suitable for utilization. It is observed that some level of variability with density occurs suggesting that there are other factors that influence compression stress perpendicular to grain other than density. Similarly observed is the fact that at $5.00 \mathrm{~N} \mathrm{~mm}^{-2}$, compression stress perpendicular to grain is very low compared to an average of $61.85 \mathrm{~N} \mathrm{~mm}^{-2}$ for compression stress parallel to grain. This agrees with similar findings by Martin et al. (2007) in E. grandis and E. terreticornis hybrid. Findings by Stalnaker and Harris (1989) and Kwame (2001) give additional confirmation. Regression analysis revealed a perfect linear relationship between compression and load across the locations.

ANOVA for compression stress perpendicular to grain shows that there was significant difference between locations while all other parameters were highly significant at $1 \%$ level of probability $(P<0.01)$ (Table 4$)$. It was clearly evident that regions one and two (bottom and middle) were different from region three (top).

\section{Comp. St.」 g. Sokoto}

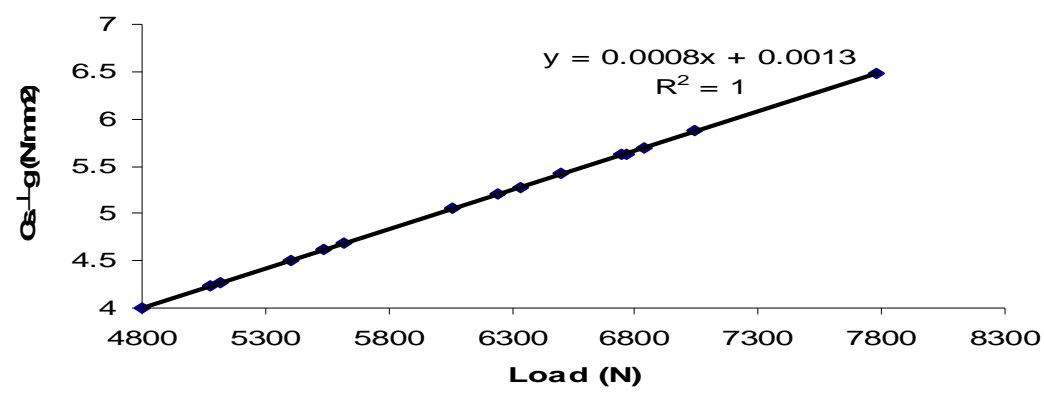

(a)

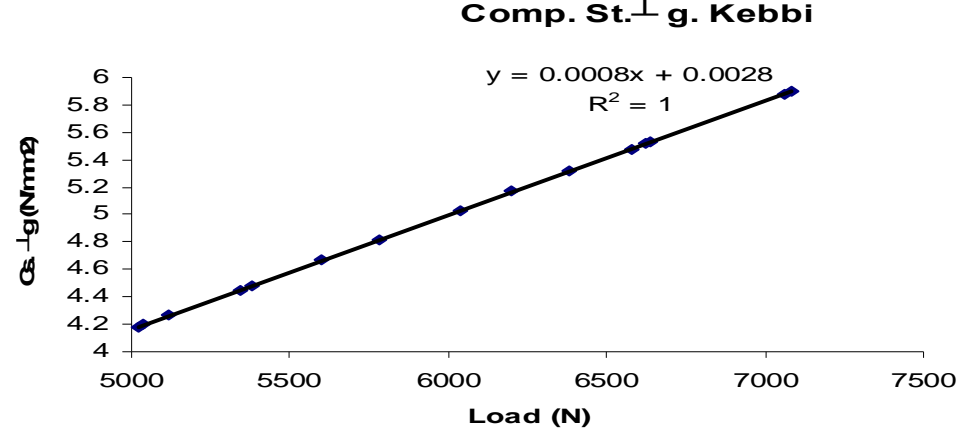

(b)

Comp. St. $\perp$ g. Zamfara

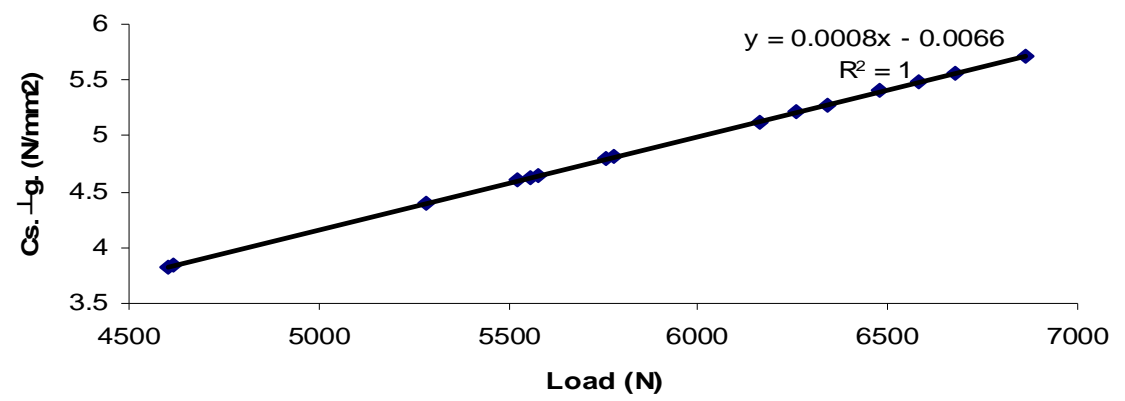

(c)

Figure 2a,b,c: Relationship between compression stress perpendicular to grain and load to failure 


\section{CONCLUSION}

Compression stress and its effect on timber fabrication has been studied in line with international standards and procedures. In comparison with other eucalyptus species and some species used for timber in Nigeria as per NCP2:1973, values obtained for E. camaldulensis were found to be moderate, thus placing the wood at an advantage. It is concluded that $E$. camaldulensis timber can be profitably exploited for timber and can thus be added to the timber menu in Nigeria as an alternative to the overstretched rainforest species in use in the country. Further research could however be carried out on other aspects of the wood for diverse end uses

\section{REFERENCES}

Ademiluyi, E.O. (1984). Saw milling Technology in Nigeria: In proceedings of the induction course in Basic Forestry, Organized by Forestry Research Institute of Nigeria (FRIN), Ibadan, pp 9.

Akpan, M. (2006). Studies on physical and mechanical properties of Neem (Azadirachta indica) A Juss wood in relation to utilization as timber in north eastern Nigeria. Unpublished Ph.D. Thesis, Department of Forestry and Wildlife Management, Federal University of Technology, Yola, Nigeria. pp 213.

ALS (American Lumber Standards) (2000). Product Standard PS 20 - 70. United States Department of Commerce, $U$ S.. Govt. Printing Office, Washington, D. C. pp 296.

Boiangu, D.D., Carageorghe, E., Rades, M.J., Ionescus, L.G., Zamfirescu, E.H., Murgulescu, S. and Sawu, M. (1982). Macanica si rezistenta meterialelor. Editora Didactica si Pedigojica, Bucuresti, pp 425.

Curtu, I. and Ghelmeziu, N. (1984). Macanica lemnilui si materialelor pe baza de lemn. Editura Tehnica. Bucuresti, 351p.

Curtu, I., Sperchez, F., Goncier, M., Firea, R. and Tudor, E. (1981). Calcul de rezistenta in industria lemnului. Editura tehnica, Bucuresti. Pp. 398.

Desch, H.E (1992). Timber: Its structure, properties and Utilization. Macmillan Educational Publications, London. 410 pp.
FPR (Forest Products Research) (1969). The strength properties of timber. Bulletin No.50. Second Edition (Metric Units) Her Majesty's Office, London. Pp 60.

Fatubarin, A. (2004). Tropical Ecology. Higher Education Handbook Series No. 1. Decency Printers and Stationeries, llorin. 68-71 pp.

Ghelmeziu, N. (1981). Lemnul exotic- Lemnul African; Proprietati si utilisari. Editura Tehnica. Bucuresti. Pp.426.

Hall, F.F. (1998). Tropical Trees and Forests. Springer publications, Berlin. Pp. 431

Kwame, J.B. (2001). Timbers of West Africa: an overview of their physical and strength properties. International Journal of Environmental Science. 54(3): 30 - 39 .

Mamman, A.B., Oyebanii, J.O. and Peters, S.W. (2000). Nigeria A people United, A Future Assured (survey of states) Vol.2.

Martin, S.A., Martin, M., Juan, C.P., Maria, A., Sossa, Z., Dora, I.V. and luis, C. (2007). Physical and Mechanical Properties of Eucalyptus grandis X E. terreticornis hybrid grown in Argentina. WwW. Inta.gov.ar/Concordia.

NCP 2 (Nigerian Code of Practice). (1973). Timber design manual. Nigerian Society of Engineers (NSE), Lagos. Pp. 71.

Ojanuga, A.G. (2004). Agro ecological zones map of Nigeria. National Special Programme for Food Security, FAO-UNESCO 124pp.

Porter, B. (2001). Carpentery and joinery 3. Butterworth Heinemann Publications, Oxford. Pp. 288.

Senchi, A.A. (2005). Preliminary study of germination technique for the seeds of gum Arabic (Acacia Senegal L. Wild). Unpublished project report Usmanu Danfodiyo University, Sokoto.

Stalnaker, J. and Harris, E.C. (1989). Structural design in wood. Van Nostrand Reinhold, New York. Pp.426.

Tarziu, D. (1983). Padurile tropicale. Editura Ceres Bucuresti. Pp. 6.

USFPL (United States Forest Products Laboratory) (2001). Wood Handbook. F.P.S, Wisconsin, pp.37 